\title{
PENGEMBANGAN MODUL BIOLOGI BERBASIS INQUIRY LESSON UNTUK MENINGKATKAN AKTIVITAS PEMBELAJARAN GURU DAN SISWA
}

\author{
Oleh \\ Syafruddin 1 ) \\ ${ }^{1)}$ Fakultas Keguruan dan Ilmu Pendidikan Universitas Samawa \\ rudyrbc77@yahoo.co.id
}

\begin{abstract}
ABSTRAK
Penelitian dan pengembangan modul ini bertujuan untuk mengetahui: 1) aktivitas pembelajaran guru dan siswa dengan menerapkan modul biologi berbasis inquiry lesson. Penelitian dan pengembangan ini menggunakan metode Borg \& Gall yang telah dimodifikasi menjadi sembilan tahapan: 1) tahap penelitian pendahuluan, 2) tahap perencanaan, 3) tahap pengembangan rancangan awal produk, 4) tahap uji coba lapangan permulaan, 5) tahap revisi produk tahap pertama, 6) tahap uji lapangan terbatas, 7) tahap revisi produk tahap kedua, 8) tahap uji lapangan operasional, 9) tahap revisi produk akhir. Model pengembangan modul menggunakan desains ADDIE (Analysis, Design, Development, Implementation, Evaluations). Instrumen yang digunakan meliputi: angket, observasi, dan wawancara. Analisis data yang digunakan selama penelitian dan pengembangan adalah analisis deskriptif dan teknik persentase. Hasil penelitian dan pengembangan menunjukkan: modul biologi yang dikembangkan oleh peneliti efektif meningkatkan aktivitas pembelajaran guru dan siswa. Hal ini dibuktikan dengan aktivitas pembelajaran guru dan siswa mengalami peningkatan pada setiap pertemuan. Pada pertemuan I rerata yang diperoleh dari aktivitas guru adalah $68,75 \%$, pertemuan II sebesar 79,17\% dan pertemuan III sebesar 93,75\%. Aktivitas siswa menunjukkan bahwa pada setiap kali pertemuan aktivitas kegiatan pembelajaran oleh siswa mengalami peningkatan. Pada pertemuan I rerata yang diperoleh dari aktivitas siswa adalah $62,5 \%$, pertemuan II sebesar 70,83\% dan pertemuan III sebesar 93,75\%.
\end{abstract}

Kata Kunci: Inquiry lesson, aktivitas pembelajaran guru dan siswa. 


\section{PENDAHULUAN}

Sains secara umum diakui sebagai suatu hal yang sangat penting dan mendasar dalam perkembangan ilmu pengetahuan dan teknologi (IPTEK). Bangsa yang tidak ingin ketinggalan dalam kemajuan dunia dituntut untuk mampu menguasai sains. Keberhasilan suatu bangsa dalam menguasai dan mengembangkan IPTEK sering kali dimulai dari penguasaan dalam pengembangan sains. Oleh karena itu pendidikan sains dipandang perlu untuk diajarkan pada generasi muda sebagai sumber daya manusia yang akan membangun suatu bangsa. Sains memiliki sifat dan karakteristik yang unik yang membedakan dari ilmu lainnya. Keunikan sains itu sering pula dinyatakan sebagai hakikat sains. Hakikat sains sebenarnya digunakan untuk menjawab secara benar pernyataan apakah sebenarnya sains itu. Sains sebenarnya sudah diujicobakan secara empiris melalui metode ilmiah, untuk itu peran metode ilmiah terhadap diterimanya sebuah pengetahuan sangatlah penting (Toharudin dkk., 2011).

Berdasarkan Permen No. 65 Tahun 2013 tentang Standar Proses Pendidikan Dasar dan Menengah, proses pembelajaran pada satuan pendidikan diselenggarakan secara interaktif, inspiratif, menyenangkan, menantang, memotivasi siswa untuk berpartisivasi aktif serta memberikan ruang yang cukup bagi prakarsa, kreatifitas dan kemandirian sesuai dengan bakat, minat dan perkembangan fisik serta psikologis siswa. Proses pembelajaran menggunakan pendekatan atau metode pembelajaran yang sesuai dengan karakteristik peserta didik dan mata pelajaran. Di antara pendekatan dan metode yang dianjurkan dalam Standar Proses tersebut adalah pendekatan saintifik, inkuiri, pembelajaran berbasis masalah dan pembelajaran berbasis projek pada semua mata pelajaran. Pendekatan/metode lainnya yang dapat diimplementasikan antara lain pembelajaran kontekstual dan pembelajaran kooperatif (Kemendikbud, 2013).

$$
\text { Mata pelajaran biologi sebagai }
$$
bagian dari bidang sains memiliki peranan penting dalam meningkatkan mutu pendidikan, khususnya didalam menghasilkan peserta didik yang berkualitas. Pesatnya perkembangan ilmu pengetahuan dan teknologi tersebut termasuk ilmu biologi membawa dampak pemilihan materi, metode, dan media pembelajaran serta sistem pembelajaran yang tepat agar dapat meningkatkan pengetahuan peserta didik sehingga dapat bersaing dalam menanggapi persaingan sains tersebut dan dapat mencapai tujuan mata pelajaran biologi itu sendiri. Pembelajaran biologi sebagai pembelajaran kontekstual berarti pembelajaran yang menghadirkan permasalahan lingkungan sekitar ke dalam kelas. Pembelajaran 
biologi merupakan pembelajaran yang bersifat kontekstual karena memfasilitasi kegiatan belajar siswa untuk mencari, mengolah dan menemukan pengalaman belajar yang lebih konkret (Trianto, 2007).

Hasil obsevasi peneliti di SMAN 1 Magelang tentang profil pemenuhan delapan Standar Nasional Pendidikan (SNP) menunjukkan kesenjangan antara skor ideal dengan skor kenyataan. Kesenjangan yang cukup besar antara skor ideal dengan skor kenyataan terdapat pada Standar Proses. Standar proses berkaitan dengan aktivitas antara siswa dengan pendidik serta lingkungannya selama proses pembelajaran. Rendahnya standar proses dipengaruhi oleh kurang optimalnya proses pembelajaran yang berlangsung di kelas. Proses pembelajaran masih berpusat pada guru (teaching center), guru masih mengedepankan produk dibandingkan dengan proses, akibatnya siswa cenderung pasif hanya menerima materi yang diajarkan sehingga siswa cenderung diam pada saat guru bertanya.

Menurut Hermawan (2007), aktifitas dalam kegiatan belajar tidak lain adalah untuk mengkontruksi pengetahuan mereka sendiri. Mereka aktif membangun pemahaman atas persoalan atau segala sesuatu yang mereka hadapi dalam kegitan pembelajaran. Aktifitas belajar siswa merupakan unsur dasar yang penting bagi keberhasilan proses pembelajaran. Melalui aktifitas, seorang siswa akan dapat memahami pelajaran dari pengalamannya, sehingga akan mempertinggi hasil belajar.

Wenning

(2010a),

mengklasifikasikan level inquiry berdasarkan sejauh mana lokus kontrol antara guru dan siswa serta kompleksitas pengalaman intelektual yang didapat siswa dalam pembelajaran. Level yang paling rendah sekaligus yang paling pundamental adalah level discovery learning, diikuti oleh interactive demonstrasi, inquiry lesson, inquiry laboratory, real work application, dan yang paling tinggi adalah hypothetical inquiry. Dengan demikian, setiap kali siswa melewati level inquiry yang baru maka siswa juga telah menguasai science process skill yang lebih komplek. Holmes (2013) dalam penelitiannya menyimpulkan bahwa pembelajaran berbasis Inquiry Lesson memungkinkan siswa untuk mendeskripsikan objek atau peristiwa, mengajukan pertanyaan, memperoleh pengetahuan, membangaun penjelasan dari fenomena alam, menguji mereka dalam menjelaskan fenomena dengan cara yang berbeda serta mengkomunikasikan ide-ide mereka dengan orang lain. Pembelajaran berbasis penemuan mampu meningkatkan kemampuan berfikir kritis siswa serta memberikan pengalaman belajar kepada siswa layaknya sebagai seorang ilmuan melalui metode ilmiah (Kizilaslan, et al., 2012) 
Berdasarkan penjelasan diatas perlu adanya bahan ajar dengan tema bioteknologi yang sesuai dengan kurikulum 2013 untuk meningkatkan aktifitas pembelajaran guru dan siswa. Solusinya adalah dikembangkan modul ajar biologi yang diintegrasikan dengan model pembelajaran berbasis inquiry lesson. Modul ajar merupakan cara pengorganisasian materi pembelajaran yang mengacu pada urutan penyajian materi pelajaran dan menunjukkan kepada siswa antara keterkaitan fakta, konsep, prosedur dan prinsip yang terkandung dalam materi pembelajaran. Modul ajar merupakan bahan ajar cetak yang disusun secara sistematis dan di dalamnya telah dilengkapi petunjuk untuk siswa belajar sendiri sehingga meminimalisir bimbingan oleh guru. modul ajar berperan sebagai penghubung pengetahuan siswa dengan objek yang dipelajari melalui kegiatan-kegiatan yang terdapat dalam modul, dan memberikan kesempatan kepada siswa untuk menguasai satu unit materi pelajaran sebelum beralih ke unit berikutnya (Prastowo, 2012; Sungkono, 2003).

\section{METODE PENELITIAN}

Penelitian ini merupakan penelitian dan pengembangan (Research \& Development) modifikasi Borg and Gall dengan langka-langkah sebagai berikut: 1) penelitian dan pengumpulan informasi termasuk kajian literatur, observasi kelas, dan membuat kerangka kerja penelitian, 2) melakukan perencanaan termasuk keterampilan mendefinisikan, menyatakan tujuan, menentukan urutan untuk penelitian dan menguji kelayakan skala kecil, 3) mengembangkan bentuk produk awal ( draft awal produk), 4) melakukan uji coba lapangan permulaan, 5) melakukan revisi terhadap produk utama, 6) melakukan uji lapangan utama, 7) melakukan revisi produk operasional, 8) melakukan uji lapangan operasional, 9) melakukan revisi produk akhir, 10) melakukan penyebaran dan implementasi produk (Borg dan Gall, 1983). Prosedur pengembangan dilakukan dengan memodifikasi tahapan menjadi sembilan langkah dengan tidak melakukan langkah kesepuluh karena pertimbangan waktu dan biaya. Model pengembangan modul yang digunakan diadaptasi dari model ADDIE (analisys, design, develovment, implementation, evaluation).

Subjek uji coba pada penelitiaan ini terdiri dari 3 kelompok subjek yang meliputi uji coba awal yaitu 4 orang validasi ahli, uji coba kelompok kecil yaitu 3 orang guru praktisi SMA dan 12 orang siswa serta uji coba lapangan operasional dilakukan pada siswa kelas XII IPA SMA Negeri 1 Magelang yang memiliki 6 kelas paralel kelas XII IPA. Subyek uji coba lapangan adalah 2 kelas dari kelas XII IPA yang akan menjadi kelas modul dan exsisting class. 
Siswa kelas XII IPA 6 berjumlah 24 menjadi kelas modul sedangkan siswa kelas XII IPA 4 berjumlah 24 menjadi exsisting class. Teknik mengambilan sample menggunakan teknik cluster random sampling.

Data analisis kebutuhaan diperoleh dari kuisioner dan wawancara terhadap siswa dan guru tentang kondisi pembelajaran di kelas, sedangkan data hasil ujian nasional dari kemendiknas, dan data ketercapaian 8 SNP di SMAN 1 Magelang yang diperoleh dari hasil wawancara dan observasi. Data hasil validasi ahli dan praktisi pendidikan diperoleh melalui angket kelayakan modul. Data hasil uji terbatas berupa data kualitatif yang diperoleh melalui angket kelayakan modul oleh siswa dan kuisioner tanggapan siswa terhadap modul pembelajaran.Instrumen pengumpulan data berupa lembar observasi untuk mengetahui aktivitas pembelajaran guru dan siswa.

Data yang diperoleh dalam penelitian ini adalah data analisis deskriptif kualitatif digunakan untuk analisis data validasi perorangan praktisi pendidikan (guru) dan uji kelompok kecil (siswa) yang berupa masukan, tanggapan, saran, dan kritik yang terdapat pada angket. Analisis deskriptif kuantitatif digunakan untuk menganalisis data yang berbentuk persentase. Teknik persentase digunakan untuk menyajikan data aktifitas pembelajaran giru dan siswa.

\section{HASIL DAN PEMBAHASAN}

\section{Analisis Kebutuhan}

Hasil penelitian dan pengembangan modul biologi berbasis inquiry lesson pada materi bioteknologi kelas XII SMA Negeri 1 Magelang diawali dengan mengidentifikasi potensi dan masalah yang akan dijadikan objek penelitian yaitu analisis kebutuhan dan analisis produk yang akan dikembangkan.

Kegiatan awal yang dilakukan adalah analisis pemenuhan 8 standar nasional pendidikan, analisis hasil Ujian Nasional tahun 2009/2010, 2010/2011 dan 2012/2013, analisis bahan ajar yang digunakan guru dan siswa, hasil angket tanggapan guru dan siswa mengenai bahan ajar serta wawancara guru dan siswa.

\section{Validasi Produk Awal}

Uji coba permulaan digunakan untuk memperoleh evaluasi kualitatif awal dari draft produk yang telah dibuat. Uji coba permulaan dilakukan dengan uji validasi ahli materi, ahli media, ahli pembelajaran, serta ahli keterbacaan. Hasil validasi oleh ahli disajikan pada gambar 1 . 


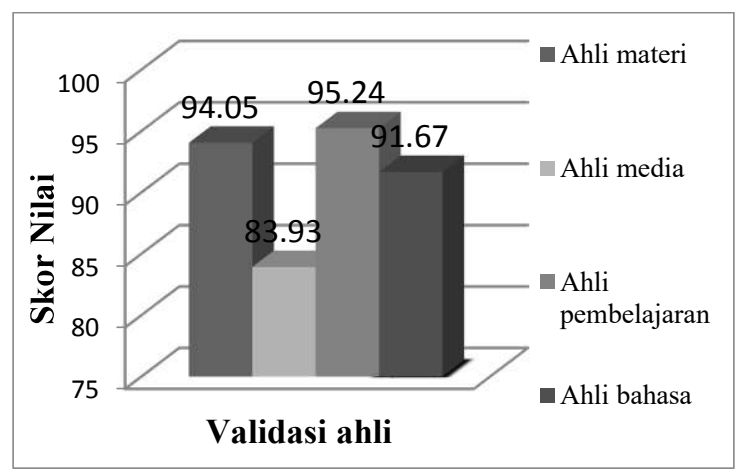

Gambar 1. Histogram Hasil Validasi

Gambar 1 menunjukkan bahwa hasil validasi dari semua validator dikategorikan sangat baik. Rata-rata persentase dari ahli materi 95,05\% kategori sangat baik, ahli media sebesar $83,93 \%$ kategori sangat baik, ahli pembelajaran $95,24 \%$ kategori sangat baik, ahli bahasa sebesar 91,67 kategori sangat baik.

\section{Uji Coba Lapangan Terbatas}

Uji lapangan terbatas bertujuan untuk memperoleh evaluasi dari pengguna lapangan atas produk modul yang telah direvisi berdasarkan hasil uji validasi ahli. Uji coba lapangan terbatas dilakukan oleh validasi perorangan praktisi pendidikan SMA (3 orang guru biologi) dan uji kelompok kecil (12 siswa) dengan instrumen berupa angket terkait tanggapan siswa terhadap modul. Hasil uji coba kelompok kecil disajikan pada gambar 2.

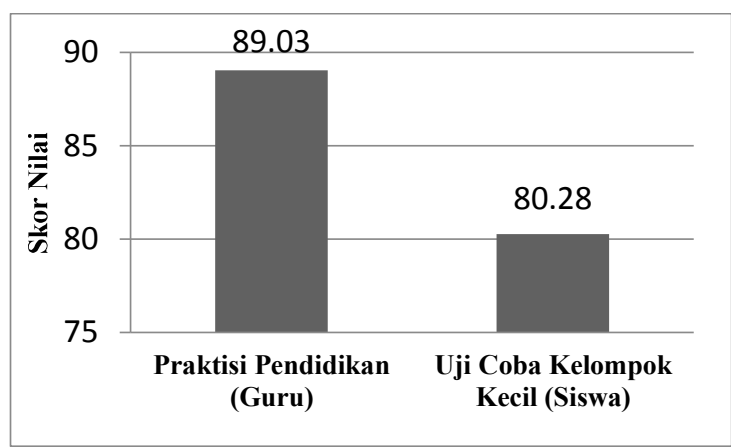

Gambar 2. Histogram Hasil Uji Coba Kelompok Kecil

Gambar 2 menunjukkan bahwa hasil validasi oleh praktisi pendidikan memperoleh skor rata-rata $89,03 \%$ dengan kategori sangat baik, sedangkan hasil uji coba kelompok kecil (12 siswa) memperoleh skor rata-rata $80,28 \%$ dengan kategori baik.

\section{Analisis aktivitas pembelajaran guru dan siswa}

Penilian aktifitas guru dan siswa dilihat berdasarkan lima sintaks, yakni observasi, manipulasi, generalisasi, verifikasi, aplikasis. Kelima sintaks ini dilihat nilai rata-rata pada tiga kali pertemuan. Hasil penilaian tersebut dirangkung dalam table berikut.

Tabel 1. Aktivitas Pembelajaran Guru

\begin{tabular}{c|c|c|c}
\hline \multirow{2}{*}{ Sintaks } & \multicolumn{3}{|c}{ \% Pertemuan } \\
\cline { 2 - 4 } & I & II & III \\
\hline Observasi & 56,25 & 75 & 93,75 \\
\hline Manipulasi & 6,75 & 81,25 & 93,75 \\
\hline Generalisasi & 100 & 100 & 100 \\
\hline Verifikasi & 75 & 75 & 75 \\
\hline Aplikasi & 75 & 75 & 100 \\
\hline Rata-rata & $\mathbf{6 8 , 7 5}$ & $\mathbf{7 9 , 1 7}$ & $\mathbf{9 3 , 7 5}$ \\
\hline \hline
\end{tabular}

Tabel 2. Aktivitas Pembelajaran Siswa

$\%$ Pertemuan 


\begin{tabular}{c|c|c|c} 
& I & II & III \\
\hline Observasi & 56,25 & 68,75 & 87,50 \\
\hline Manipulasi & 56,25 & 75 & 100 \\
\hline Generalisasi & 75 & 50 & 100 \\
\hline Verifikasi & 75 & 75 & 75 \\
\hline Aplikasi & 75 & 75 & 100 \\
\hline Rata-rata & $\mathbf{6 2 , 5 0}$ & $\mathbf{7 0 , 8 3}$ & $\mathbf{9 3 , 7 5}$ \\
\hline \hline
\end{tabular}

Hasil aktivitas kegiatan selama pembelajaran menggunakan modul biologi berbasis inquiry lesson untuk kelas modul menunjukkan bahwa pada setiap kali pertemuan aktifitas kegiatan pembelajaran mengalami peningkatan. Pada pertemuan I rerata yang diperoleh dari aktivitas guru adalah $68,75 \%$, pertemuan II sebesar $79,17 \%$ dan pertemuan III sebesar 93,75\%. Aktivitas siswa menunjukkan bahwa pada setiap kali pertemuan aktivitas kegiatan pembelajaran oleh siswa mengalami peningkatan. Pada pertemuan I rerata yang diperoleh dari aktivitas siswa adalah $62,5 \%$, pertemuan II sebesar 70,83\% dan pertemuan III sebesar 93,75\%. Berdasarkan hasil observasi aktivitas pembelajaran dengan modul berbasis inquiry lesson lebih mudah digunakan oleh guru maupun siswa.

\section{PEMBAHASAN}

Produk yang akan dikembangkan adalah modul biologi berbasis inquiry lesson. Kurikulum yang dipakai dalam penelitan ini adalah kurikulum 2013. Modul dibuat berdasarkan sintaks Inquiry Lesson yaitu obsrevation, manipulation, generalization, verifikation dan aplication. Wenning (2010b), menyatakan bahwa dalam inquiry lesson siswa mengidentifikasi prinsip sains dan atau hubungan antar prinsip (cooperative work untuk membangun pengetahuan yang lebih detail). Dalam level ini guru mulai menunjukkan proses ilmiah secara eksplisit kepada siswa untuk memahami bagaimana cara memformulasikan suatu eksperimen, mengidentifikasi, mengontrol variabel dan lain sebagainya. Pada tahap ini pula siswa sudah diarahkan pada kegiatan percobaan ilmiah, akan tetapi siswa masih mendapatkan bimbingan langsung dari guru. Donald (2012) dalam penelitiannya menyatakan bahwa strategi pembelajaran inquiry dapat diterapkan sebagai usaha untuk meningkatkan pertisipasi belajar siswa dengan mengajarkan siswa berfikir secara ilmiah seperti seorang ilmuan dan mengarahkan siswa untuk berfikir secara ilmiah,

Karakteristik yang membedakan modul berbasis Inquiry Lesson dengan modul lainnya adalah modul yang akan dikembangkan diintegrasikan dengan metode Inquiry Lesson, karena siswa dilibatkan secara aktif dalam penemuan konsep. Menurut Permendikbud nomor 65 tahun 2013 salah satu prinsip pembelajaran yang digunakan adalah siswa mencari tahu. Salah satu pembelajaran yang disarankan 
pada kurikulum 2013 adalah metode Inquiry. Siswa belajar mengemukakan pertanyaan dan mengumpulkan bukti-bukti dari berbagai sumber untuk menjawab permasalahan yang ditemukan, serta mempertanggungjawabkan secara ilmiah atas kesimpulan yang telah dibuat. Pembelajaran inquiry membantu siswa untuk belajar mengenai isi sains, menguasai bagaimana melakukan sains, dan memahami sifat-sifat sains (Zion et al., 2007).

Modul berbasis Inqquiry Lesson yang dikembangkan disusun sesuai dengan komponen-komponen yang harus terdapat dalam modul. Satu paket modul biasanya memiliki komponen petunjuk guru, lembar kegiatan siswa, lembaran kerja siswa, kunci lembaran kerja, lembaran tes dan kunci lembaran tes. Sistematika isi modul yang dibuat juga lebih mengutamakan kegiatan siswa yang diletakkan sebelum uraian materi dengan tujuan siswa akan lebih aktif dan mengkonstruk pengetahuan secara efektif. Uraian materi juga diletakkan mengikuti urutan kegiatan sehingga siswa lebih mudah dalam memahami setiap poin penting yang harus dikuasai oleh siswa. Setiap sub-bab materi akan diberikan latihan soal untuk tolak ukur kemampuan siswa setelah mempelajari materi. Kegiatan siswa pada setiap sub-bab materi mengacu pada basis Inquiry Lesson yang dikemas dalam modul yang menyatu dalam konseptualnya, hal ini bertujuan agar siswa dapat melakukan kegiatan penyelidikan secara mandiri maupun secara kelompok.

Modul yang dikembangkan oleh peneliti terdiri dari modul siswa dan modul guru. Modul siswa berbasis Inquiry Lesson terdiri atas tiga bagian yaitu bagian awal, bagian inti dan bagian penutup. Bagian awal terdiri atas: judul modul, petunjuk penggunaan modul biologi berbasis inquiry lesson, peta isi modul, kompetensi inti, kompetensi dasar dan indikator. Bagian inti terdiri dari: tujuan pembelajaran, alur kegiatan, kegiatan belajar (menurut sintaks inquiry lesson), info bio, materi, latian soal, dan refleksi diri. Bagian penutup terdiri dari: uji kompetensi, kunci jawaban, glosarium dan daftar pustaka. Modul guru berbasis Inquiry Lesson merupakan konfirmasi dari modul siswa yaitu berisi jawaban dari modul siswa. Modul menurut Daryanto (2009) dapat dirumuskan sebagai: sarana pembelajaran dalam bentuk tertulis atau cetak yang disusun secara sistematis, memuat materi pembelajaran, metode, tujuan pembelajaran, metode, tujuan pembelajaran berdasarkan kompetensi dasar atau indikator pencapaian kompetensi, petunjuk kegiatan belajar mandiri (self instruktional) dan memberikan kesempatan kepada siswa untuk menguji diri sendiri melalui latihan yang disajikan dalam modul tersebut. Modul berbasis inquiry lesson berisikan 
kegiatan pembelajaran yang mendorong siswa untuk menganalisis, memecahkan permasalahan berdasarkan fakta-fakta yang ditemukan sehingga diperoleh pemahaman konseptual sehingga pembelajaran yang didapat siswa lebih bermakna (Rusche $\&$ Jason, 2011). Wenning (2005) juga menekankan bagi siswa yang belum akrap dengan pendekatan eksperimen yang lebih canggih, Inquiry Lesson tepat untuk mengenal kegiatan eksperimen. Pedagogi dari Inquiry Lesson adalah suatu kegiatan Inquiry yang didasarkan pada guru perlahan melepaskan siswa untuk melakukan inkuiri dengan menyediakan bimbingan dan pernyataan untuk membantu siswa dalam proses penyelidikan (Wenning, 2011).

Kelayakan prototipe modul berbasis Inquiry Lesson pada materi bioteknologi diuji melalui tahap: a) uji coba permulaan: validasi ahli materi, ahli media ahli keterbacaan, ahli pembelajaran; b) uji lapangan terbatas: praktisi pendidikan dan uji kelompok kecil. Draf produk awal yang telah dibuat kemudian diajukan kepada validator yang telah ditentukan oleh peneliti. Validasi dilakukan untuk memperbaiki desain produk yang telah dikembangkan agar sesuai dengan baku mutu pengembangan sebuah produk.

Hasil valisasi oleh ahli materi memperoleh rata-rata $94,06 \%$ dengan kategori sangat baik, hasil validasi oleh ahli media diperoleh skor rata-rata $83,93 \%$ dengan kategori sangat baik, hasil validasi oleh ahli pembelajaran berupa RPP dan penilaian diperoleh skor rata-rata 95,24\% dengan kategori sangat baik dan hasil keseluruhan validasi oleh ahli keterbacaan diperoleh skor rata-rata $91,67 \%$ dengan kategori sangat baik.

Uji coba lapangan awal produk pengembangan melibatkan 12 orang siswa dengan instrumen berupa angket terkait tanggapan siswa terhadap modul dan 3 orang praktisi pendidikan SMA dengan instrumen berupa angket terkait tanggapan guru. Hasil uji coba skala kecil yaitu 12 orang siswa memperoleh skor rata-rata yaitu sebesar 80, 28\% kategori baik. Hasil validasi oleh tiga orang praktisi memperoleh hasil skor rata-rata 89,03\% dengan kategori sangat baik. Berdasarkan uji kelayakan diatas maka maka modul biologi berbasis inquiry lesson layak untuk diujicoba lapangan operasional.

Aktivitas pembelajaran guru dan siswa diukur dengan menggunakan intrumen observasi. Observasi dilakukan oleh 3 orang observer untuk mengetahui sejauh mana aktivitas pembelajaran guru dan siswa menggunakan modul biologi berbasis inquiry lesson. Hasil aktivitas kegiatan selama pembelajaran menggunakan modul biologi berbasis inquiry lesson untuk kelas modul menunjukkan bahwa pada setiap kali pertemuan aktifitas kegiatan pembelajaran 
mengalami peningkatan. Pada pertemuan I rerata yang diperoleh dari aktivitas guru adalah $68,75 \%$, pertemuan II sebesar $79,17 \%$ dan pertemuan III sebesar 93,75\%. Aktivitas siswa menunjukkan bahwa pada setiap kali pertemuan aktivitas kegiatan pembelajaran oleh siswa mengalami peningkatan. Pada pertemuan I rerata yang diperoleh dari aktivitas siswa adalah $62,5 \%$, pertemuan II sebesar $70,83 \%$ dan pertemuan III sebesar 93,75\%. Berdasarkan hasil observasi aktivitas pembelajaran dengan modul berbasis inquiry lesson lebih mudah digunakan oleh guru maupun siswa. Hal ini diperkuat oleh hasil penelitian Hussains (2011) yang menyimpulkan bahwa pembelajaran dengan metode inquiry dapat meningkatkan prestasi belajar siswa secara signifikan dibandingkan dengan metode tradisional. Penelitan Kumari (2013) menyimpulkaan bahwa pendekatan pembelajaran inquiry berpengaruh signifikan secara statistik dibandingkan dengan pembelajaran tradisional terhadap prestasi belajar siswa, pendekatan pembelajaran inquiry yang dinitegrasikan dengan modul membuat pengalaman belajar siswa lebih bermakna dan siswa secara aktif terlibat dalam proses belajar. Pendekatan pembelajaran inquiry dianggap penting karena menekankan pada keterlibatan siswa dalam mendapatkan pengalaman melalui keterlibatan langsung dalam pembelajaran. Penelitian yang dilakukan oleh Vilagonzalo menyatakan bahwa siswa yang diajarkan dengan pembelajaran berbasis Inquiry mendapatkan skor yang lebih tinggi dari pada yang diajarkan melalui metode tradisional. Penelitian yang dilakukan oleh Shih (2010) menyatakan bahwa siswa yang diajarkan dengan pembelajaran berbasis masalah mendapatkan nilai yang positif terhadap hasil belajar siswa karena pembelajaran berbasis masalah membantu siswa dalam membangun pengetahuan mereka sendiri sehingga pengalaman belajar siswa lebih bermakna. Penelitian yang dilakukan oleh Brickman (2009) dalam penelitiannya menyatakan bahwa pembelajaran berbasis masalah dapat meningkatkan kemampuan literasi sains siswa karena pembelajaran berbasis masalah siswa membangun keterampilan mereka melalui proses ekperimental. Penelitian ini juga menyimpulkan bahwa siswa yang diajarkan dengan metode penyelidikan lebih percaya diri dalam kemampuan ilmiah mereka. Penelitian Nuangchalerm dan Thammasenna (2009) juga melaporkan bahwa pembelajaran inquiry dapat meningkatkan keterampilan berfikir analitis dan perkembangan kemampuan kognitif siswa. Berdasarkan penelitian tersebut, peran guru untuk menyiapkan pertanyaan- pertanyaan yang menyangkut masalah-masalah lingkungan sekitar kerena dapat berdampak pada 
kemampuan kognitif siswa yang lebih baik dari pada yang hanya menggunakan bahasa untuk berkomunikasi tanpa menggunakan pengalaman nyata yang dimiliki siswa. Penelitian Khan dan Iqbal (2011) melaporkan pembelajaran inquiry dengan kegiatan eksperimen dapat berdampak positif terhadap perkembangan keterampilan ilmiah siswa. Berdasarkan penelitian tersebut, pembelajaran inquiri terbimbing melatih siswa menjadi lebih aktif belajar, sedangkan guru berusaha membimbing, melatih dan membiasakan siswa untuk teraampil menggunakan alat, terampil merangkai percobaan dan mengambil kesimpulan yang merupakan tujuan pembelajaran IPA dalam melakukan metode ilmiah dan sikap ilmiah siswa. Kegiatan ekspemen dapat melatih siswa untuk merekam semua data, fakta yang diperoleh melalui hasil pengamatan dan bukan data opini hasil pemikiran. Eksperimen dapat membelajarkan siswa terlibat secara aktif sebagai upaya meningkatkan sikap ilmiah siswa, karen penemuan fakta dan data metode observasi dari sebuah eksperimen mempunyai peranan yang sangat penting bagi peningkatan sikap ilmiah siswa.

Berdasarkan data tersebut diatas dapat dikatakan bahwa modul biologi berbasis Inquiry Lesson pada materi bioteknologi efektif digunakan untuk meningkatkan aktivitas pembelajaran guru dan siswa kelas XII SMA Negeri 1 Magelang. Penelitian Trna (2012) menyatakan bahwa pembelajaran berbasis inquiry dalam pembelajaran sains berhasil diterapkan sebagai metode pembelajaran yang cocok karena memotivasi siswa dalam belajar. Pembelajaran berbasis penemuan memfasilitasi peserta didik mengumpulkan data dan menarik suatu kesimpulan dengan cara mereka sendiri. Guru bertindak sebagai fasilitator yang menciptakan situasi belajar yang berbeda dan memfasilitasi siswa untuk menyelidiki dan mengambil pengalaman belajar yang berbeda (Kulshrestha, 2014). Pembelajaran menggunakan modul berbasis inquiry lesson secara efektif akan dapat mengubah konsepsi siswa menuju konsep ilmiah, sehingga pada gilirannya hasil belajar mereka dapat ditingkatkan seoptimal mungkin baik dari segi kualitas maupun kuantitasnya dapat menghindari adanya kesalahan pemahaman konsep/ miskonsepsi. Hasil penelitian Stringer (1996), menyatakan bahwa pembelajaran modul dalam pembelajaran konsep dapat mengubah miskonsepsi siswa menuju konsep ilmiah.

Wenno (2008) mengemukakan bahwa melakukan pembelajaran dengan modul membuat siswa lebih mudah memahami konsep/materi sehingga hasil belajar siswa dapat meningkat. Pembelajaran yang baik dan menyenangkan adalah pembelajaran yang memberikan 
kesempatan kepada siswa tentang ide/gagasan yang dimiliki. Proses pembelajaran tersebut akan mendorong siswa untuk terlibat secara aktif dan membangun pengetahuan, sikap, serta perilaku. Pembelajaran dengan menggunakan modul berbasis inquiry lesson mendorong siswa untuk lebih aktif dalam melakukan eksperimen, membuktikan rumusan masalah, berdiskusi, dan komunikatif dalam menjelaskan hasil eksperimen, sehingga hal tersebut mendorong peningkatan hasil belajar siswa. Hal tersebut diperkuat dengan hasil penelitian Holmes (2013) yang menyimpulkan bahwa pembelajaran berbasis Inquiry Lesson memungkinkan siswa untuk mendeskripsikan objek atau peristiwa, mengajukan pertanyaan, memperoleh pengetahuan, membangaun penjelasan dari fenomena alam, menguji mereka dalam menjelaskan fenomena dengan cara yang berbeda serta mengkomunikasikan ide-ide mereka dengan orang lain. Dalam penelitian Trnova (2014) menyatakan bahwa proses pembelajaran berbasis Inquiry merupakan pendekatan yang tepat untuk mengembangkan kreatifitas antara guru dan siswa. Prinsip dari pembelajaran Inquiry adalah kegiatan penemuan siswa, kebermaknaan isi, mengembangkan berfikir kritis, serta memotifasi siswa terhadap ilmu sains merupakan komponen dasar kreatifitas siswa. Penelitian yang dilakukan oleh Panasam dan Nuangchalerm (2010) yang menyatakan bahwa pembelajaran berbasis projek dan pembelajaran berbasis masalah efektif dan efesien diterapkan dalam pembelajaran karena hasil penelitian menunjukkan bahwa dua kelompok siswa yang diajarkan dengan metode tersebut mendapatkan hasil yang sama dalam hal hasil belajar, keterampilan proses sains dan kemampuan berfikir analitik siswa, oleh karena itu guru sains bisa menerapkan kedua metode tersebut dalam pembelajaran untuk mencapai tujuan yang diharapkan. Penelitian Bilgin (2009) menyatakan bahwa penggunaan inquiry dapat meningkatkan hasil belajar dan pemahaman konsep siswa karena menghadirkan permasalahan sebagai kegiatan pembelajaran dapat memperbaiki lingkungan belajar siswa dan membantu siswa untuk lebih aktif belajar. Permasalahan yang diberikan sesuai dengan sintaks inquiry dapat membantu siswa untuk belajar memaknai permasalahan yang membuat hubungan antar konsep, meningkatkan partisipasi siswa dalam pembelajaran melalui kegiatan diskusi kelompok.

\section{SIMPULAN}

Berdasarkan hasil penelitian dan pengembangan menunjukkan bahwa modul biologi yang dikembangkan oleh peneliti 
efektif meningkatkan aktivitas pembelajaran guru dan siswa. Hal ini dibuktikan dengan aktivitas pembelajaran guru dan siswa meningkat pada setiap pertemuan. Pada pertemuan I rerata yang diperoleh dari aktivitas guru adalah $68,75 \%$, pertemuan II sebesar 79,17\% dan pertemuan III sebesar 93,75\%. Aktivitas siswa menunjukkan bahwa pada setiap kali pertemuan aktivitas kegiatan pembelajaran oleh siswa mengalami peningkatan. Pada pertemuan I rerata yang diperoleh dari aktivitas siswa adalah $62,5 \%$, pertemuan II sebesar 70,83\% dan pertemuan III sebesar $93,75 \%$.

Berdasarkan kesimpulan, maka perlu dilakukan perbaikan dan saran dalam pemanfaatan produk lebih lanjut antara lain: (1) modul yang dikembangkan dapat dijadikan sebagai salah satu rujukan dalam pengembangan bahan ajar oleh guru yang memerlukan keterampilan, serta validasi dari yang kompeten sehingga dapat dihasikan produk modul yang lebih baik, (2) modul berbasis inquiry lesson menekankan pada proses penemuan sehingga diperlikan sarana dan prasarana yang memadai untuk menunjang kegiatan praktikum, (3) penerapan modul berbasis inquiry lesson hanya terbatas pada satu sekolah yaitu SMA Negeri 1 Magelang . Oleh karenanya, perlu adanya penelitian lebih luas mengenai hal tersebut, (4) modul biologi berbasis inquiry lesson pada materi bioteknologi memerlukan pengujian lebih luas (desiminasi dan implementasi) untuk menyempurnaan tahap penelitian pengembangan yang dilakukan, (5) modul biologi berbasis inquiry lesson mungkin dapat dikembangkan untuk materi lain yang sesuai.

\section{DAFTAR PUSTAKA}

Hussain, A., Azzem, M., \& Shakoor, A. 2011. Physics Teaching Methods Scientific Inquiry VS Tradisional Lecture. International Journal of Humanities and Social Science, vol. 1, no. 19, hlm. 269-276.

Bilgin, I. 2009. TheEffects of Guided Inquiry Instruction Incorporating a Cooperative Learning Approach on University Students' Achievement of Acid and Bases Concepts and Attitude Toward Guided Inquiry Instruction.Scientific Research and Essay. 4 (10):1038-1046.

Borg, Walter R \& Gall, Meredith D. 1983. Education research. An introduction. Longman. New York \& London.

Brickman, P., Golmally, C., Armstrong, N. 2009. Effects of Inquiry-based Learningon Students' Science Literacy Skills and Confidence. International Journal for the Scholarship of Teaching and Learning, vol. 3, no. 2, hlm. 1-22.

Daryanto. 2013. Menyusun Modul. Yogyakarta: Gava Media.

Donald, G. 2012. Teaching Critical \& Thinking in High School Biology?.Journal of The American 
Biology Teacher, 74 (3). USA: University of California press.

Trnova, E. \& Trna, J. 2014. Implementation of Creativty in Science Teacher Training. International Journal on New Trend in Education and Their Implication, vol. 5, issue. 3. hlm 54-63.

Holmes, V-L. 2011. Standardising the Inquiry Lesson:Improving the Caliber of Science Inquiry. Electronic Journal of Literacy Through Science, vol. 10, hlm. 119.

Trna, J., Trnova, E., \& Sibor, J. 2012. Implementation of Inquiry Based Science Education in Science Teacher Training. International Journal On New Trend In Education And Their Implication, vol. 2, issue 4. hlm. 199-209.

Kementerian Pendidikan dan Kebudayaan. 2013. Standar Proses Pendidikan Dasar dan Menengah. Jakarta: Kemendikbud.

Khan, M, \& Iqbal, M. Z. 2011. Effect of Inquiry Lab Teaching Method on the Development of Scientific Skills Through the Teaching of Biology in Pakistan. 11 (1): Pakistan.

Kizilaslan, A., Sozbilir, M., \& Yasar, M. D. 2012. Inquiry Based Teaching In Turkey: A Content Analysis of Research Reports. International Journal of Environmental \& Science Education. 7 (4): 599-617.

Kulshrestha, A.K., Shing, A., \& Kumari, K. 2013. How To Develop Inquiry Based Learning Material International Journal of Aplied and Studies, vol. 2, issue 5, hlm 972-975.

Kumari, K. \& Kulshrestha, A.K. 2013. Impact of Contstructivist Inquiry-
Based Learning Approach on Science Achievement at Grade VIII. International Journal of Aplied and Studies, vol. 2, issue 10, hlm 1-5.

Nuangchalerm, P. \& Thammasena. 2014. Inquiry-based Learning in China: Lesson learned for School SciencePractices. Journal of Social Sciences, vol. 10, no. 13, hlm. 64-71.

Panasam, M. \& Nuangchalerm, P. 2010. Learning Outcomes of ProjectBased and Inquiry-Based Learning Activities. Journal of Social Sciences 6 (2): 252-255.

Prastowo, A. 2012. Panduan Kreatif Membuat Bahan Ajar Inovatif. Yogyakarta: Diva Press.

Rusche, S. N,\& Jason, K. 2011."You Have to Absorb Yourself in It": Using Inquiry and Reflection to Promote Student Learning and Selfknowledge. American SociologicalAssociation.39(4).DO I: $10.1177 / 0092055 X 11418685$ : SAGE.

Shih, J-L., Chuang, C-W., \& Hwang, G-J. 2010. An Inquiry-based Mobile Learning Approach to Enhancing Social Science Learning Effectiveness. Educational Technology \& Society, 13 (4), 5062.

Sungkono. 2003. Pengembangan Bahan Ajar. Yogyakarta: FIP UNY.

Stringer, R. T. 1996. Action research: A handbook for practitioners. London: International Educational and Profesional Publisher.

Toharudin, U., Hendrawati, S., \& Rustaman, A.R. 2011. Membangun Literasi Sains Peserta Didik. Bandung: Humaniora. 